\title{
Structural Analysis of Reproductive Development in Staminate Flowers of Laurus nobilis $\mathrm{L}$.
}

\author{
Özlem AYTÜRK, Meral ÜNAL \\ Marmara University, Department of Biology, Göztepe Campus, 34730 Istanbul, Turkey; oayturk2004@hotmail.com
}

\begin{abstract}
Male (staminat) flower development, being separated in 8 phases, was investigated in Laurus nobilis (Lauraceae) through the usage of histological sections and scanning electron microscopy (SEM) analysis. Flower development starts when apical meristem differentiates, followed by the conversion of this structure to floral meristem. Initial development phases comprise incidents similar to the ones of the female flower. 4 tepals and 8-10 stamens primordia develop through floral meristem in turn. In early stages of the development, sexual dimorphism occurs when the carpel primordium arrests. Filaments carry 2 nectaries in stamens which arise in 3 whorls. Anther wall consists of epidermis, endothecium, 2 or 3 middle layers and a single-layered glandular tapetum. Anthers are bisporangiate. Meiotic division is regular in pollen mother cells, and pollen grains do not contain aperture. Beside the pollen scattered individually within the pollen sacs, groups which contain some pollen tied to each other are rarely observed, as well. Pollen grains seldom germinate within microsporangium. Anthers are opened with 2 valves which widen from the base through the top. Accumulation of polysaccharides, lipids and proteins were identified by histochemical methods in stamens. These organic substances are greater within and around the vascular bundle compared to other tissues.
\end{abstract}

Keywords: anther valves, dioecious, Laurus nobilis L., staminate flower development

\section{Introduction}

Sex determination mechanism in dioecious species, which contain approximately 10\% (Dellaporta and Calderone-Urea, 1993), appears analogous to the system in animal species, significantly. Hence, dioecious plants and animals are considered as remarkable examples of parallel evolution.

Generally, unisexual flower development is categorized in 2 main types (Mitchell and Diggle, 2005). In not only male but also in female flowers, in frequent Type I development, stamen and pistil begin to be formed; however, in one flower, only androecium or gynoecium reaches functional maturity. Asparagus officinalis L. (Caporali et al., 1994), Silene latifolia L. (Grant et al., 1994) and Zea mays (Cheng et al., 1983) display this sort of development. In Type II development, only one of the sex organs of unisexual flowers develops. In this sort of development, mature flowers do not carry rudimentary organ. This development is documented in Mercurialis annua L. (Durand and Durand, 1991), Spinacia oleracea L. (Sherry et al., 1993), and Thalictrum dioicum L. (Di Stilio et al., 2005).

In a number of unisexual flowers in some species of Poaceae family, while organ atrophy is eventuated through vacuolation and cell death, in some species of the family, cellular disruption is not observed through atrophy process (Kinney et al., 2008). In Panicoideae family, gynoecium abortion in staminate flower is characterized by vacu- olation and the loss of cytoplasmic organelles and nucleus disruptions (LeRoux and Kellogg, 1999).

Evolution of sex dissolution in plants is among the most significant subjects that concern biologists, because outbreeding mechanisms are significant means for genetical diversity and reinforcing vital continuity, as well. Moreover, emerging of the development stages of flower organs is a significant division of plant developmental biology, due to the its' being one of the main basic topics (Kinney et al., 2008).

Only male or female flowers are formed on the trees of L. nobilis species which belongs to Laurus genus of Lauraceae family (Cengiz, 1979; Floridata, 1996).

No report has been published of the early male and female flower development in Lauraceae although it seems to be very significant, not only for dioecious flower development but also for the knowledge of sexual dimorphism. The development of pistillate and staminate flower were examined in 2 studies in details and the developmental differences and similarities were established in $L$. nobilis. In the present study, it has been analyzed the course of events starting from the initiation of male flower up to anther dehiscence and arrest development of carpel based on histological sections and scanning electron microscopy (SEM) techniques. Having analyzed the morphological characteristics of the male flowers, reproductive biology of the species was aimed to be elucidated. The present data will provide a new look at these aspects in L. nobilis which 
32

has economical and medical importance due to its variety of essential oils.

\section{Materials and methods}

Flowers of $L$. nobilis at various stages of development were collected from Göztepe Campus of Marmara University, from November of 2008 to June of 2009. Firstly, female flowers were morphologically analyzed by stereomicroscope (Olympus 970931). The lengths of flower parts were measured and the samples were prepared for light and SEM analysis. The material was fixed in aceticalcohol $(1: 3, \mathrm{v} / \mathrm{v})$ and then placed in a vacuum desiccator to facilitate the penetration of the fixative into the plant tissues. After embedding in paraffin, blocks were sectioned at $8-15 \mu \mathrm{m}$ by Leica RM2235 rotation microtome and sections were stained with hematoxylin. For cytochemical analysis, sections were stained with Periodic acid-Schiff (PAS) (Feder-O'Brien, 1968) for insoluble polysaccharides, Coomassie brilliant blue for proteins and Sudan Black B (Pearse, 1961) for lipids. The aceto-orsein squash method was also used in the study of microsporogenesis. Pollen grains were stained with Cotton blue prepared in lactophenol to evaluate pollen fertility. Each group was counted for 1000 pollen grains, and pollen viability percentages were calculated.

The preparations were photographed with an Evolution LC color camera and an Olympus BH-2 microscope, and the images were analyzed with Image-Pro Express Version 6.0 scientific image processing and analysis software. For SEM analysis, the plant material was fixed in $2.5 \%$ glutaraldehyde in $50 \mathrm{mM}$ cacodylate buffer, pH 7.0 (Platt et al. 1983) and then dehydrated with an increasing ethanol gradient: from $70 \%$ up to $100 \%$. Then, the material for drying were kept in various percentages of ethanolHMDS solution at room temperature (Topçuoğlu et al. 2009). Then, coated with $11 \mathrm{~nm}$ of gold by using an automated sputter coater and then examined with a SEM (JEOL JMS-59 10LV).

\section{Results}

In male and female flowers of $L$. nobilis, the sex organs initiation occur similarly but their development are totally different. As in female flower, apical meristem differentiate from vegetative meristem is transformed into floral meristem in male flower, and flower sex organ primordia develop from floral meristem in turn.

In incidents that take place in following phases, there are differences between female and male flowers.

\section{Flower morphology}

Male flowers in L. nobilis start to differentiate from shoot apical meristem in October-November. Flowering occurs between March and May. Flowers grouped in three or five (Fig. 1a), are covered with bud scales (Fig. 1b and 1c). Mature male flower's height is between 5.7-6.2 mm, which is, more or less, double size of female flower.

In the outermost whorl of the flower, there are 4 yellow tepals in approximately $5 \mathrm{~mm}$ (Fig. 1d), and there are 8-10 stamens with an average height of $5.6 \mathrm{~mm}$ inside them (Fig. 1d and 1e). In the middle of filaments, 2 yellow nectaries with an average width of $1.2 \mathrm{~mm}$ and an average height of $0.7 \mathrm{~mm}$ develop (Fig. 1e).

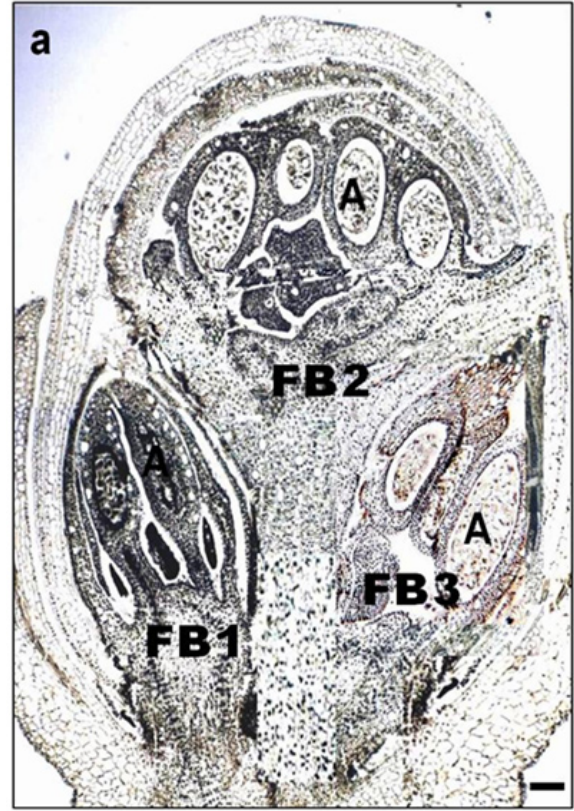

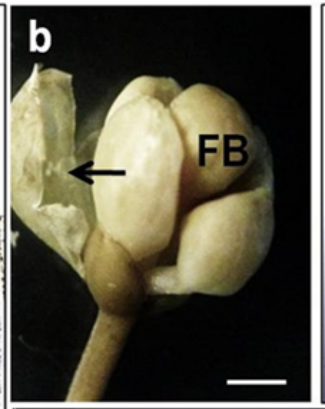

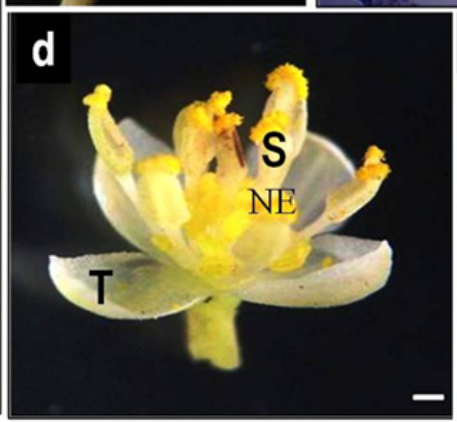

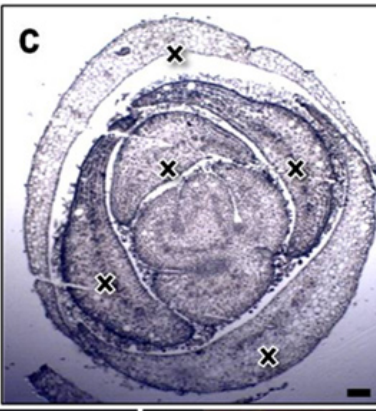

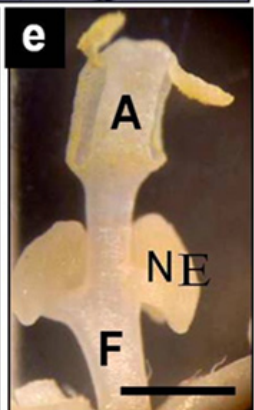

Fig. 1. a. Longitudinal section of male group with 3 flower buds, Bar $200 \mu m$; b. Flower buds group is covered by bud scales $(\rightarrow)$, Bar $1 \mathrm{~mm}$; c. Longitudinal sections of young flower with bud scales (x), Bar $100 \mu \mathrm{m}$; d. Stereomicrograph of a mature male flower, Bar $1 \mathrm{~mm}$; e. Stereomicrograph of a stamen with opened valves, Bar $1 \mathrm{~mm}$; T-Tepal; FB-Flower bud; A-Anther; S-Stamen; NENectarium; F-Filament 
Tab. 1. Morphological indications and respective lengths of floral buds in Laurus nobilis L. at various stages of development

\begin{tabular}{cccc}
\hline Stage & Morphological indications & $\begin{array}{c}\text { Bud Length } \\
(\mathrm{mm}), \mathrm{n}: 25\end{array}$ & $\begin{array}{c}\text { Fig. } \\
\text { Numbers }\end{array}$ \\
\hline 1 & Initiation of floral meristem & 1.03 & $3 \mathrm{c}$ \\
2 & Initiation of tepal primordium & 1.12 & $2 \mathrm{~b}, 3 \mathrm{c}, 3 \mathrm{~d}$ \\
3 & Initiation of stamen primordium & 1.34 & $2 \mathrm{c}, 3 \mathrm{~d}, 3 \mathrm{e}$ \\
4 & Initiation of carpel primordium & - & - \\
5 & Stamen development & 1.42 & $4 \mathrm{a}$ \\
\hline 6 & Microsporogenesis & 1.75 & $6 \mathrm{~d}$ \\
7 & Formation of two-celled pollen & 2.17 & $7 \mathrm{~d}$ \\
\hline 8 & Shedding of pollen & 3.62 & $8 \mathrm{~d}-\mathrm{f}$ \\
\hline
\end{tabular}

Up to 200 mature flowers were investigated under stereomicroscobe, and stamen numbers are 8-10, however as 12 in one and 14 in another flower. Furthermore, in merely $2 \%$ of the flowers, it is observed that not only carpel primordium occured in the phase where 2 thecae differentiate in stamens, but also the differentiation of the carpel primordium do not continue but remains only as a bulge. (Fig. 3g-i). Due to the fact that carpel primordium differentiation is not observed in every flower, it was not demonstrated in Tab. 1, in which development phases are presented.

\section{Flower development}

While male flower development was examined starting from the apical meristem differentiation to anther dehiscence, the bud lengths are measured in order to identify the alterations those occur during the development, and being divided into 8 stages, the development was analysed through stereomicroscopy, light microscopy and SEM (Tab. 1).

\section{Initiation of floral meristem}

Initially, apical meristem differentiates as an incisive bulge (Fig. 2a; Fig. 3a). Apical meristem cells, which have youthful leaves on both sides (Fig. 2a; Fig. 3a) and consist of smooth and sequential cell layers (Fig. 3b), thin walled, isodiametric and rich in cytoplasm, as well. Subsequently, apical apex widens and flattens. Afterwards, floral mer-

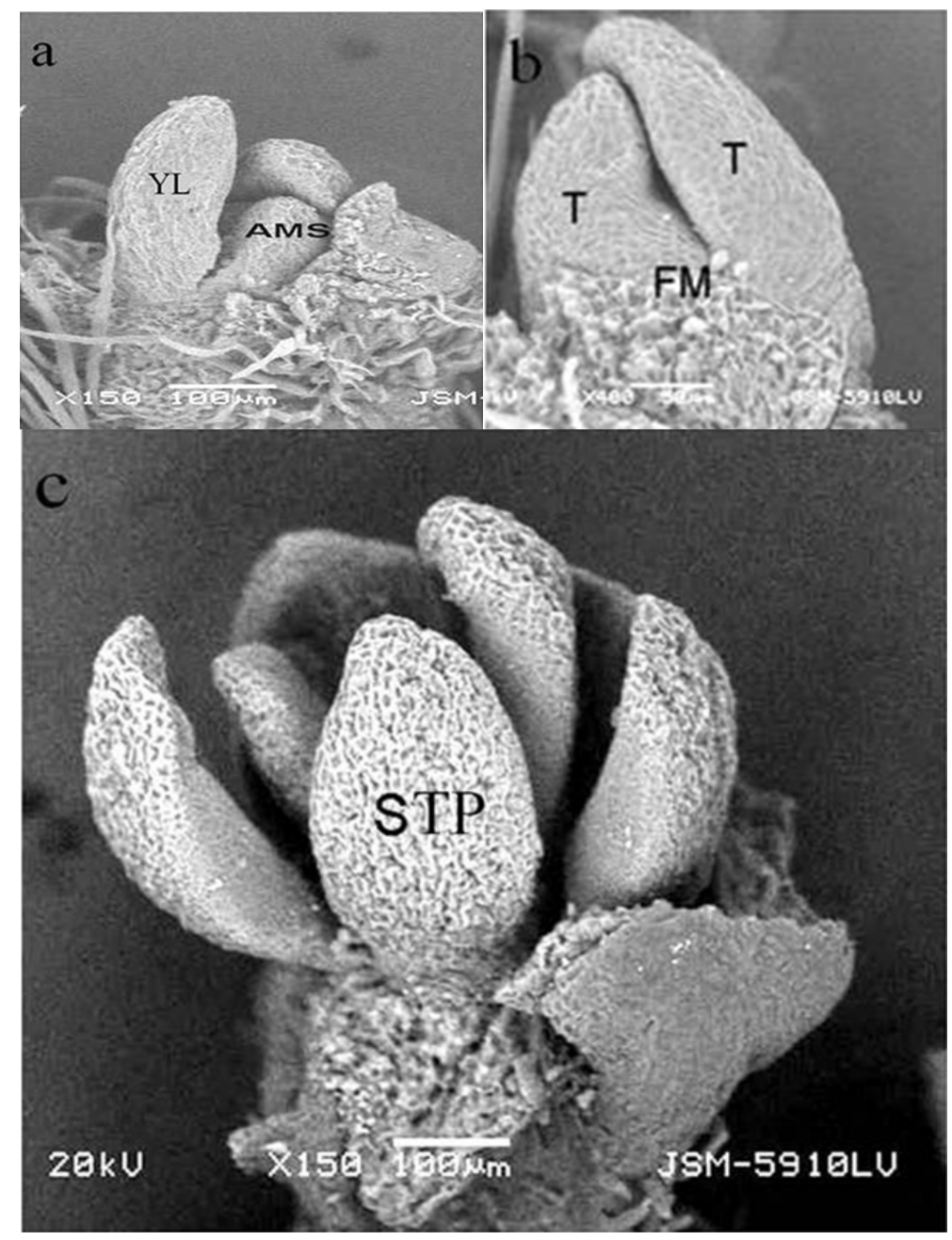

Fig. 2. Floral organogenesis in male flower viewed with scanning electron microscope. All bud scales have been removed in all. a. Apical meristem; b. First 2 tepals primordia; c. Stamens primordia; AMS-Apical meristem; YL-Young leaf; FM-Floral meristem; T-Tepal; STP-Stamen primordium 
34

istem, which has greater width and smaller depth compared to apical meristem arises (Fig. 2b; Fig. 3c). Floral meristem cells which resemble apical meristem cells are thin walled, rich in cytoplasm, and they contain many small vacuoles and a big nucleus within many nucleolus.

\section{Initiation of tepal primordium}

First, 4 tepals those are found on the outer ring differentiates from the floral meristem (Fig. 2b; Fig. 3c, 3d). In the first stages of the development, where buds range approximately $1.1 \mathrm{~mm}$ in length, tepals appear sequently on stamen primordia, as a protuberance part on both sides of floral meristem, and while extending, they form a wide dome (Fig. 3c, 3d).

\section{Initiation of stamen primordium}

Differentiation of tepal primordia is completed by the time stamen primordia start to come into existence, however their extending and widening continue (Fig. 3d).

After the increase in the diameter of floral meristem, stamen primordia those start to become visible through the upper side of floral meristem as 3 whorls shape in rows (Fig. 2c; Fig. 3d, 3e).

Stamens on the middle whorl start to differentiate between and inner side of stamen primordia those become visible previously; similarly, stamens on the innermost whorl start to differentiate between and inner side of stamen primordia, those become visible previously on the middle whorl. The total number of differentiated stamens reach to a level of 8-10, and they line up on floral apex in a ringed order.

\section{Initiation of carpel primordium}

A structure of a carpel is never originated at most of the male flowers. It remains as a small bulge (Fig. 3g-i) in three of the 200 experimental flowers. Additionally, with carpel taking progress, stigma and style differentiated but ovary failed to become swollen in one of them. In carpel that remains as a bulge, cells loose their meristematic features, transforming into prolonged cells those contain a big vacuole, cytoplasm, and a nucleus with few nucleoli pushed to the base (Fig. 3h).

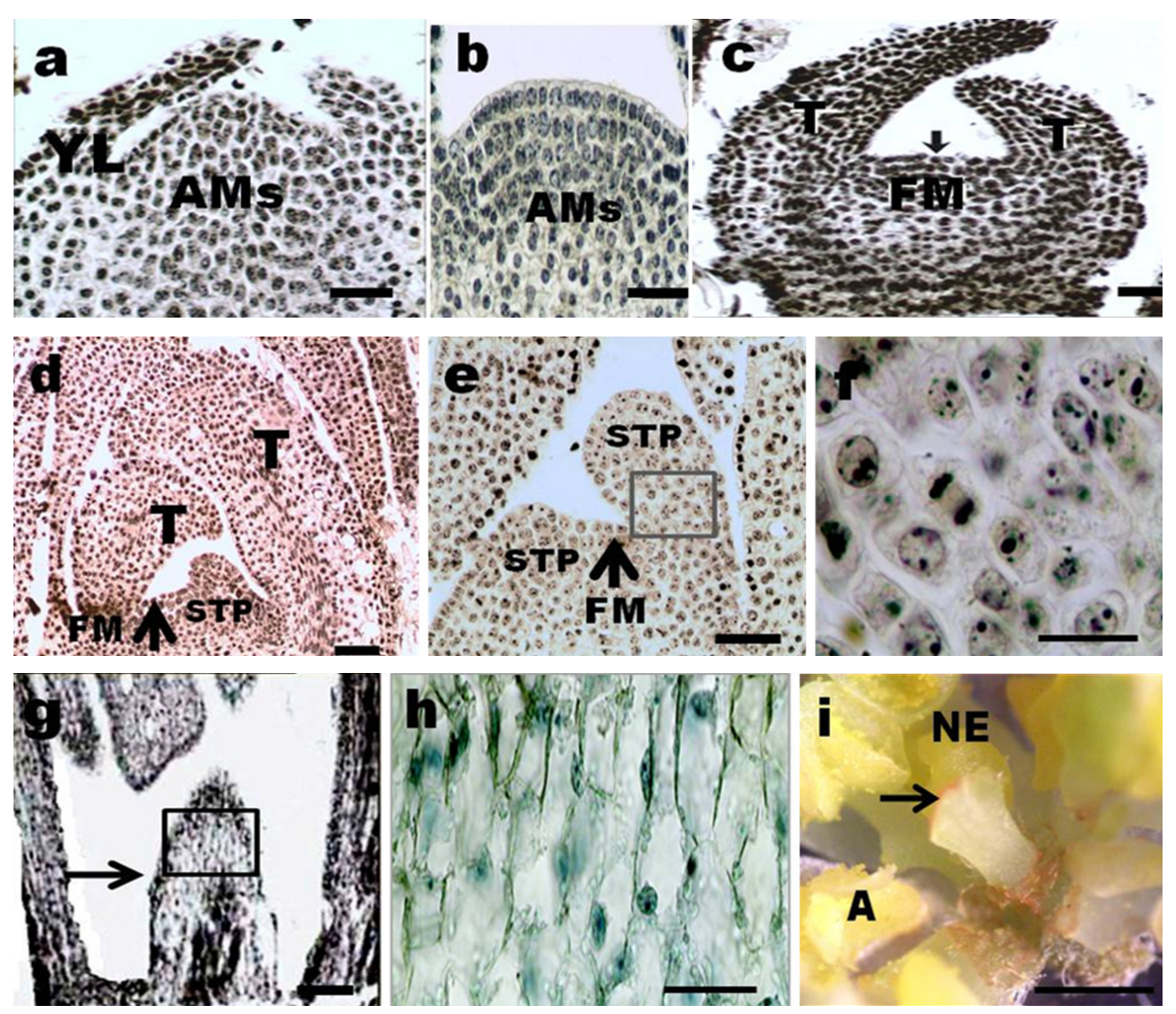

Fig. 3. Floral organogenesis. All bud scales have been removed in all. a. Apical meristem and 2 young leaves in the youngest flower, Bar $100 \mu m$; b. Regular cell layers of apical meristem, Bar $100 \mu m$; c. Floral meristem $(\rightarrow)$ and 2 tepals initiations, Bar $100 \mu m$; d. Floral meristem $(\rightarrow), 2$ tepals and stamen primordium, Bar $100 \mu m$; e. Initiation of 2 stamen primordia, Bar $100 \mu m$; f. Stamen primordium cells, Bar $10 \mu \mathrm{m}$; g, h. Arrested development of carpel primordium $(\rightarrow)(\mathrm{g})$, Bar $100 \mu \mathrm{m}$ and cellular details of carpel primordium at the portions marked in g, (h) stained with Coomassie brilliant blue, Bar $10 \mu \mathrm{m}$; i. Stereomicrograph of arrested carpel. Fertile stamens and nectarium are present around carpel, Bar $1 \mathrm{~mm}$. AMs-Apical meristem; YL-Young leaf; FM-Floral meristem; T-Tepal; STP-Stamen primordium; N-Nectarium; A-Anther 


\section{Stamen development}

The anthers of the stamens on the innermost whorl start to mature earlier compared to those on the outer whorls. Afterward, the one in between and ultimately, the outermost anthers develop. In mature flower, the filaments of the stamens on the outermost line are the longest, the ones of the middle are a bit shorter than them, and the filaments of the mid most stamens are the shortest ones. In other words, the mid most stamens are the ones with the shortest filaments, and also the ones whose anthers mature the earliest.

Filament, in a stamen, is considerably short and thick (Fig. 4a), and it grows taller and becomes thin in the future stages (Fig. 4a-d). When filaments are noticeably short and pollen mother cells are in the early stages of meiosis, 2 nectaries emerge as a small bulge on the both sides of the filament at the same time (Fig. 5a) and they grow fast (Fig. 5a-d). Nectaries remain almost at the same size from the stage that pollen grains become visible in and to the end of the stage in which anthers dehiscence.

When anther, filament and nectarium primordia start to differentiate and mature in stamen, vascular bundles appear in every tissue (Fig. 4c, 4d; Fig. 5a-d). In the stage, in which sporogenous tissue is present, a group of meristem cells to constitute vascular bundles those are dissimilar from anther tissue cells, is realized. These cells are thin and long, and they compose 2 or 3 lines next to each other.

Idioblast cells are observed in all male flower parts and development stages being seen in young and mature tissues (Fig. 4c, 4d; Fig. 5a, 5b). When tissues become mature, idioblast cells loose their nuclei, they show vacuolization and expansion. Idioblast cells in different tissues look alike morphologically.
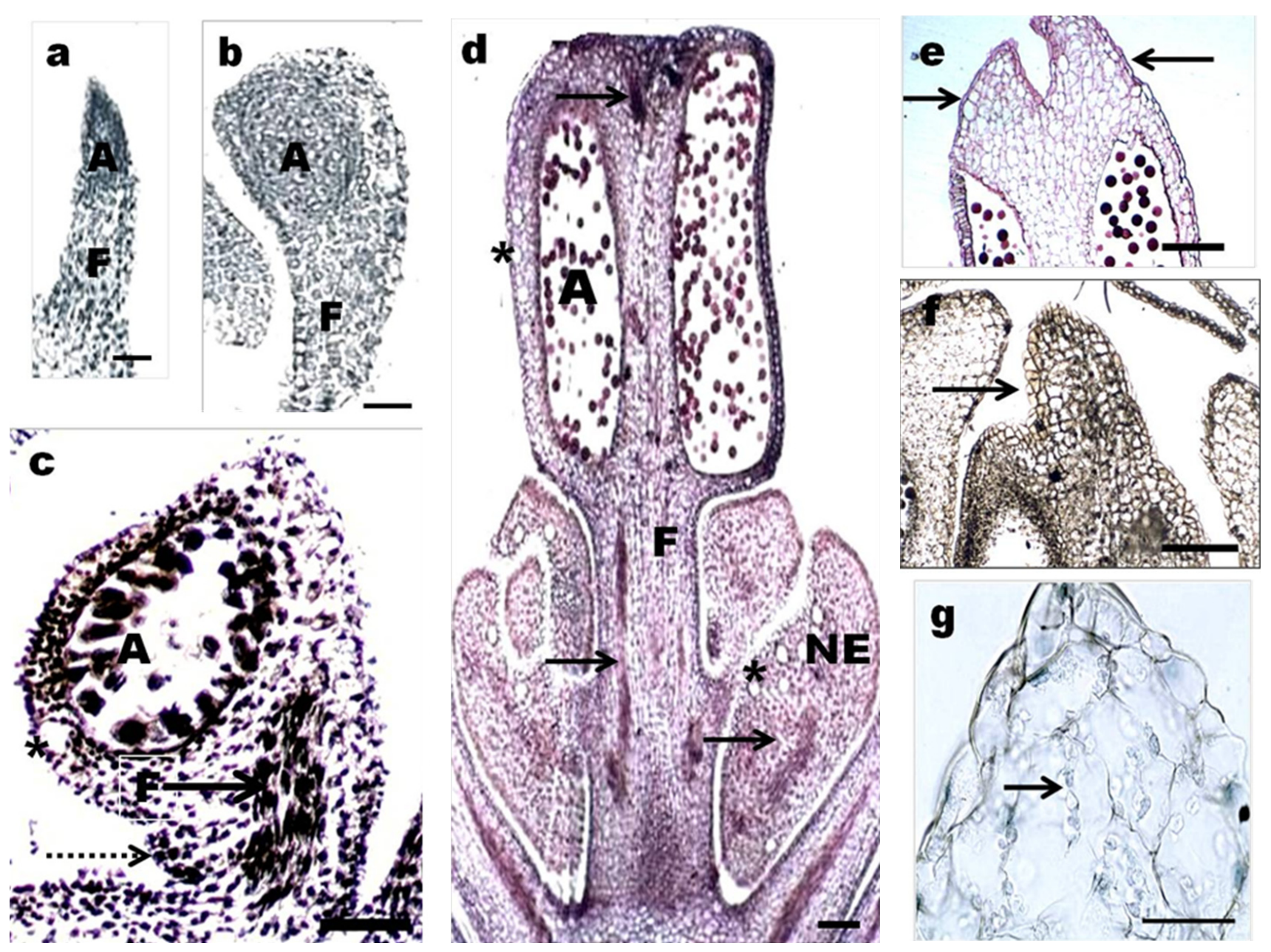

Fig. 4. Stamen development. a-c: Only one of 2 microsporangia is seen in an anther. a. Young stamens primordium with filament and newly differentiated anther stained with Coomassie brilliant blue, Bar $50 \mu m$; b. The sporogenous cells in anther stained with Coomassie brilliant blue, Bar $50 \mu m$; c. Expanding microsporangium and filament with vascular bundle $(\rightarrow)$ and a nectarium, as a small projection on the filament $(\rightarrow)$, Bar $100 \mu \mathrm{m}$; d. A complete stamen consisting of an anther with 2 microsporangia and filament with vascular bundles $(\rightarrow)$ and nectarium, stained with PAS, Bar $100 \mu \mathrm{m}$; e, f. Appandages at mature anther, Bar $100 \mu m$; g. Celllular details of appandage and starch grains $(\rightarrow)$ stained with Coomassie brilliant blue, Bar $50 \mu m$. A-Anther; F-Filament; NE-Nectarium; Idioblast cells $\left(^{*}\right)$ 
36

\section{Anther development}

Anthers in L. nobilis contain 2 microsporangia; thus, they are bisporangiate (Fig. 5a). Anther development is divided into phases considering their morphological preferences. In very young phase, when filament is considerably short, the anther starts to differentiate at the tip of filament. Anther consists of 3 diverse tissues: epidermis, sporogenous tissue and vascular tissue.

The very young anther is small and, being surrounded by an epidermis. It is composed of meristematic cells with thin walls, big nuclei and dense cytoplasm (Fig. 6a). Young anther is in elliptical shape, and it assumes, gradually, twolobed apperance with each lobe possessing a hypodermal tissue of archesporial cells. They can be distinguished from the surrounding cells with their way to lengthen slightly, prominent nuclei, big size and comparably more intensive cytoplasm (Fig. 6b).

The archesporial cells divide periclinally to give out primary parietal cells toward the epidermis, while give out primary sporogenous cell toward the interior of the anther. Having been the origin of anther wall layers, primer parietal cells constitute anther wall layers.

Sporogenous tissue

Sporogenous tissue derived by the sucsessive divisions of the primary sporogenous cells consists of polygonal cells containing intensive cytoplasm, a big and central nucleus and very small intercellular spaces (Fig. 6c). Sporogenous tissue cells increase their numbers before entering meiosis (Fig. 6d) with each lobe possessing a hypodermal tissue of archesporial cells.

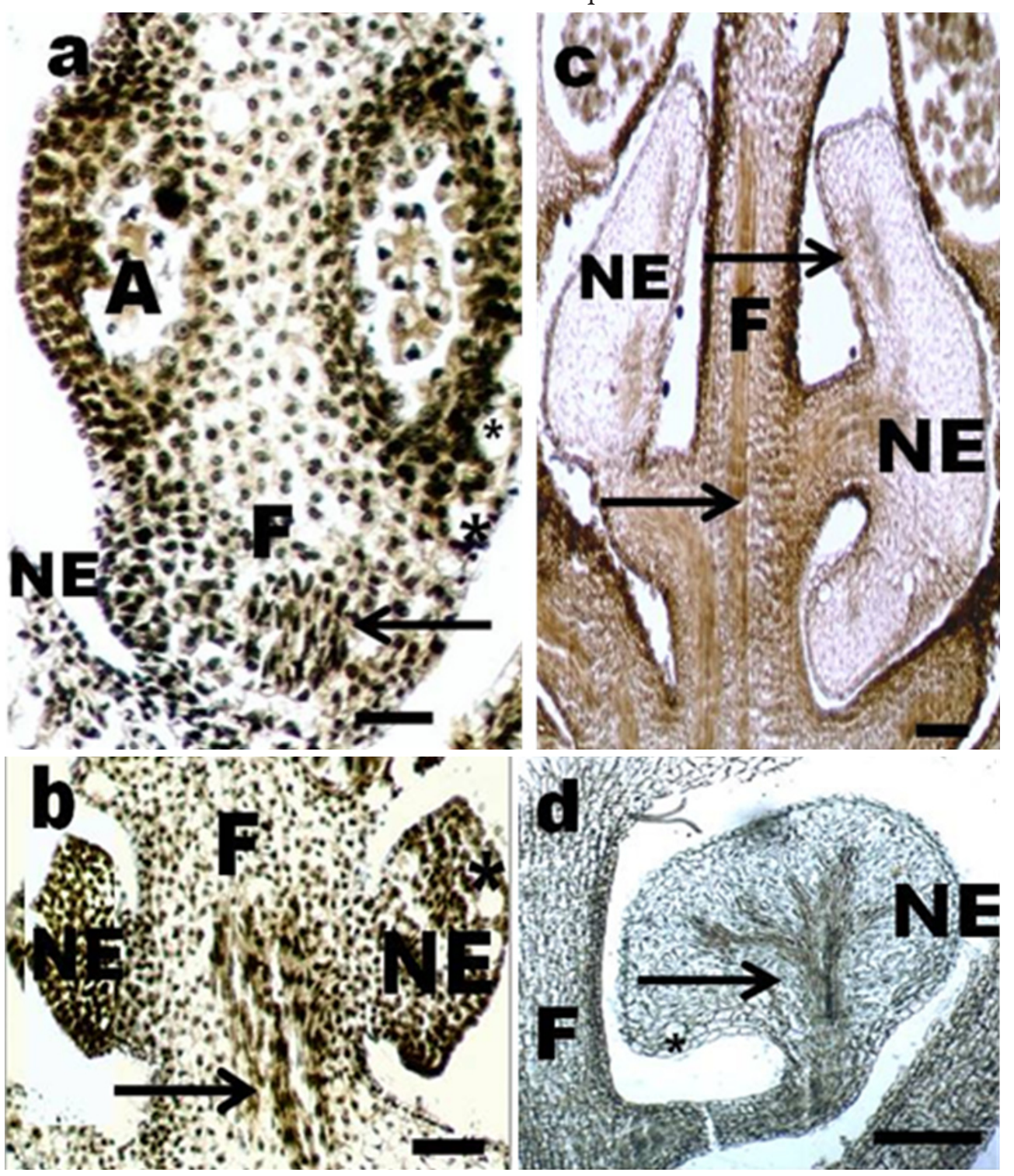

Fig. 5. a-d. Development of a nectarium from young to mature, showing gradual changes. a, b. Stained with hematoksilen, Bar $100 \mu m$; c. Stained with Sudan Black B, Bar $100 \mu m$; d. Stained with Coomassie brilliant blue. An extensive networks of veins in the nectarium are remarkable, Bar $100 \mu \mathrm{m}$. A-Anther; F-Filament; Vascular bundles $(\rightarrow)$; NE-Nectarium, Idioblast cell $\left(^{*}\right)$ 


\section{Development of anther wall layers}

The mature anther wall consists of 4 cell layers which are epidermis, endothecium, middle layers and tapetum from outside to inside.

Epidermis is composed of small cells those are enlarged to become more conspicuous (exothecium) (Fig. $6 \mathrm{~g})$. Big nucleus, which holds a place near to the centre, comes closer to the edge, while cells swell and take the oval shape (Fig. 6j). Cuticle layer which covers epidermis gives a stronger positive reaction with Sudan Black B.

Endothecium consists of single layer of small cells in the phase that PMCs are formed (Fig. 6g). They elongate radially in mature anther (Fig. 6j). In endothecium cells, wall thickenings arise in phases where young pollen grains are located in pollen sacs, and these thickenings continue to exist without disruption till the phases in which pollen grains are shed (Fig. 6g, 6i, 61). The thickenings of endothecial cell walls on the upper part of the anther valve are considerably more than other parts of it (Fig. 61). By the time pollen mature, decrement in endothecium cell volume is observed. Wall thickenings in endothecium give strong
PAS positive reaction (Fig. 6k). At the time of dehiscence, the exothecium and endothecium are still intact.

The middle layers, which consist of 2 or 3 lined, flattened small cells (Fig. 6d), lengthen slightly during development. Afterwards, cells start to enlarge and finally, in the phase in which pollen mature, while flattening, crushed and completely disappear with the pressure of surrounding tissues (Fig. 6g-1).

Secretory tapetum surrounding the anther locules is composed of a single layer of large cells characterized by the presence of dense cytoplasm and prominent nuclei. When PMCs are in very early stage of meiosis (leptone$\mathrm{ma}$ ), tapetal cells undergo mitosis. Tapetal cells with $2 \mathrm{nu}$ clei (Fig. 6e) or rarely 4 nuclei (Fig. 6f) appear and they reach their biggest size at the end of prophase I (Fig. $6 \mathrm{~g}$ ). The fusion of nuclei may happen and as a result, a polyploid nucleus in irregular shaped occurs in a cell (Fig. 6h).

In young pollen stage, tapetum starts to break down in very early stage of development (Fig. 6i, j), the free protoplasts surround the pollen grains. First, tapetal cytoplasm becomes highly vacuolated and starts collapsing inwards

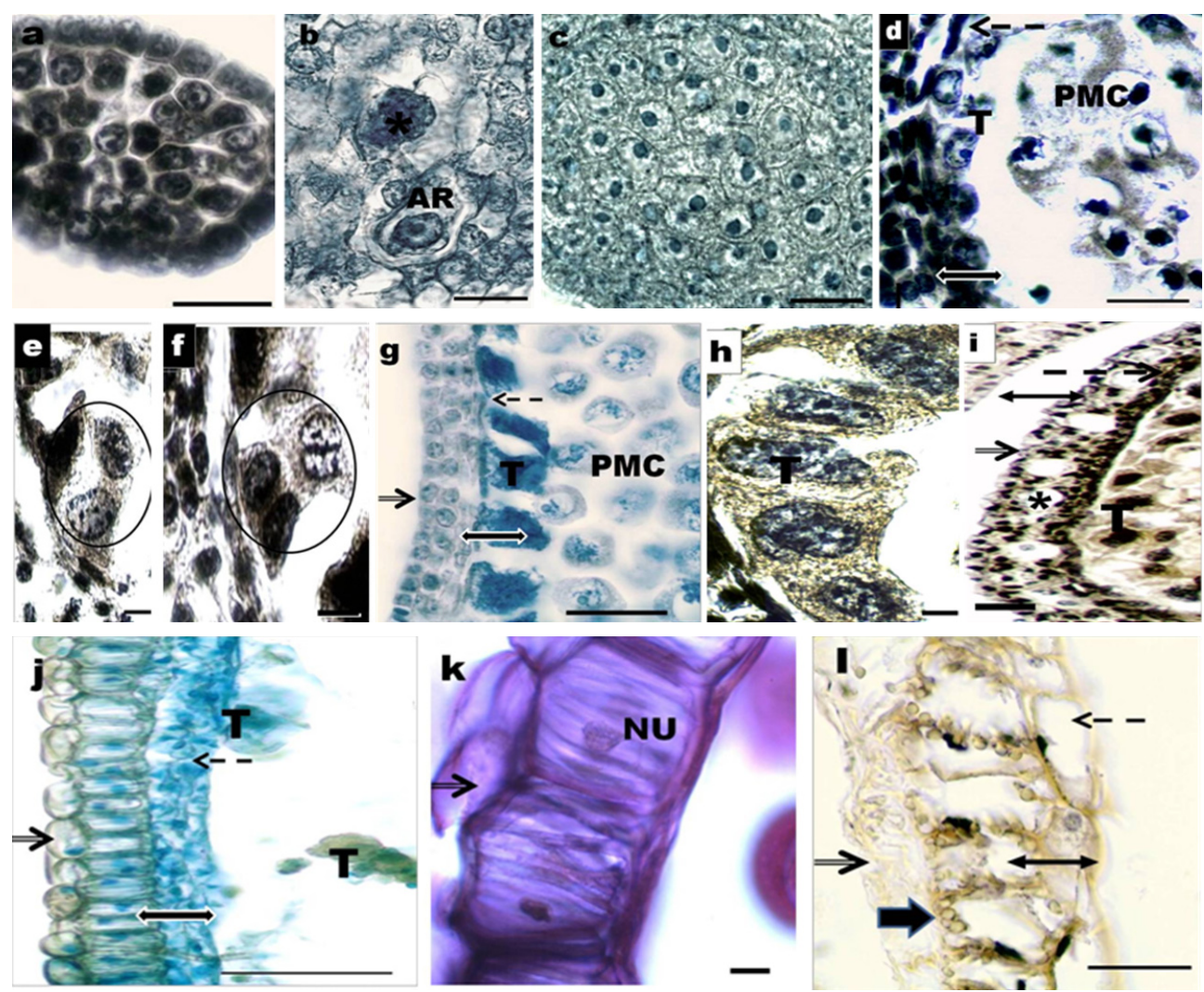

Fig. 6. a. Young, undifferentiated anther tissue, Bar $50 \mu \mathrm{m}$; b. Archesporial cell stained with Coomassie brilliant blue, Bar $50 \mu \mathrm{m}$; c. Sporogenous tissue stained with Coomassie brilliant blue, Bar $50 \mu \mathrm{m}$; d. Young anther wall layers and newly differentiated pollen mother cells, Bar $100 \mu \mathrm{m}$; e, f. The tapetal cells with 2 nuclei (e) and 4 nuclei (f), Bar $10 \mu \mathrm{m}$; g. Anther wall layers and PMCs at meiosis I (leptonema) stained by Coomassie brilliant blue, Bar 100 $\mu m ;$ h. Big tapetal nuclei formed by the nuclear fusion, $B a r 10 \mu m ;$ i, $j$. Anther wall layers at the stage of young pollen, stained with Coomassie brilliant blue (j), Bar $200 \mu \mathrm{m}$; k. Wall thickenings in endothecium stained by PAS, Bar $10 \mu \mathrm{m} ; 1$. Anther wall of late pollen development. The tapetum is completely degenerated, whereas the starch grains (thick arrows) are still visible at this stage within the endothecium, Bar $100 \mu \mathrm{m}$. T-Tapetum; AR-Archesporium; Idioblast cell $\left(^{*}\right)$; NU-Nucleus, Epidermis $(\rightarrow)$, Endothecium $(\leftrightarrow)$, Midlle layer $(\rightarrow)$. 
38

through cell wall. By this time, tapetum, appearing quite empty with the small vacuoles inside, there are some cells with 2 nuclei. The remainders of tapetum are still evident at stage of 2-nucleated pollen grains (Fig. 6j).

\section{Microsporogenesis}

When the PMCs first arise, they contain centrally located nuclei, appear isodiametric and have 1-2 starch grains in their intensive cytoplasm (Fig. 6d). Meiotic division in PMCs is regular and small pollen grains with central nuclei and dense cytoplasm come into existence.

\section{Formation of 2-celled pollen}

A freshly formed small pollen undergoes a rapid expansion and vacuoles appear (Fig. 7a). As a result of mitotic division, 2-celled pollen grain with a larger vegetative cell and a smaller generative cell is formed (Fig. 7b).

\section{Histochemistry}

While starch grains are not observed in anther tissues in the period where sporogenous tissue is formed, few starch grains are encountered in pollen mother cells, anther wall layers and the connective tissue when meiosis begins. The amount of starch grains in these tissues increases while the development makes progress.

Starch grains are evident in the cytoplasms of pollen grains in one-celled and two-celled stage. Starch grains in endothecium in young anther are more than the ones in other wall layers. In mature anther, starch grains are observed on a limited scale in only endothecium, while other wall layers do not contain starch (Fig. 61).

In valve parts of mature anthers, starch distribution shows dissimilarity. The number of starch grains are in small amount in upper and lower areas of the valves, while distribution in middle areas are considerably intensive.

Wall thickenings in endothecium give positive reaction for proteins, lipids and polysaccharides, as revealed by Coomassie brilliant blue, Sudan Black B and PAS, respectively.

Exine gives a strong positive reaction with Coomassie brilliant blue and Sudan Black B while intin stains strongly with PAS and Coomassie brilliant blue in the stages between one-nucleated stage and the stage in which pollen grains were discarded from anther. These histochemical tests indicate that exine is made up of lipoidal substances and proteins while intin composed of insoluble polysaccharides and proteins.

Vascular bundles in anther, filament, nectarium and tepals are stained much stronger with PAS (Fig. 4d), Coomassie brilliant blue (Fig. 5d) and Sudan Black B (Fig. 5c) compared to the surrounding tissues, and they contain more starch grains compared to the surrounding cells.

\section{Anther dehiscence}

Anther valves open and pollen grains are shed to nature, after pollen grains become two-celled. In young phase, an-
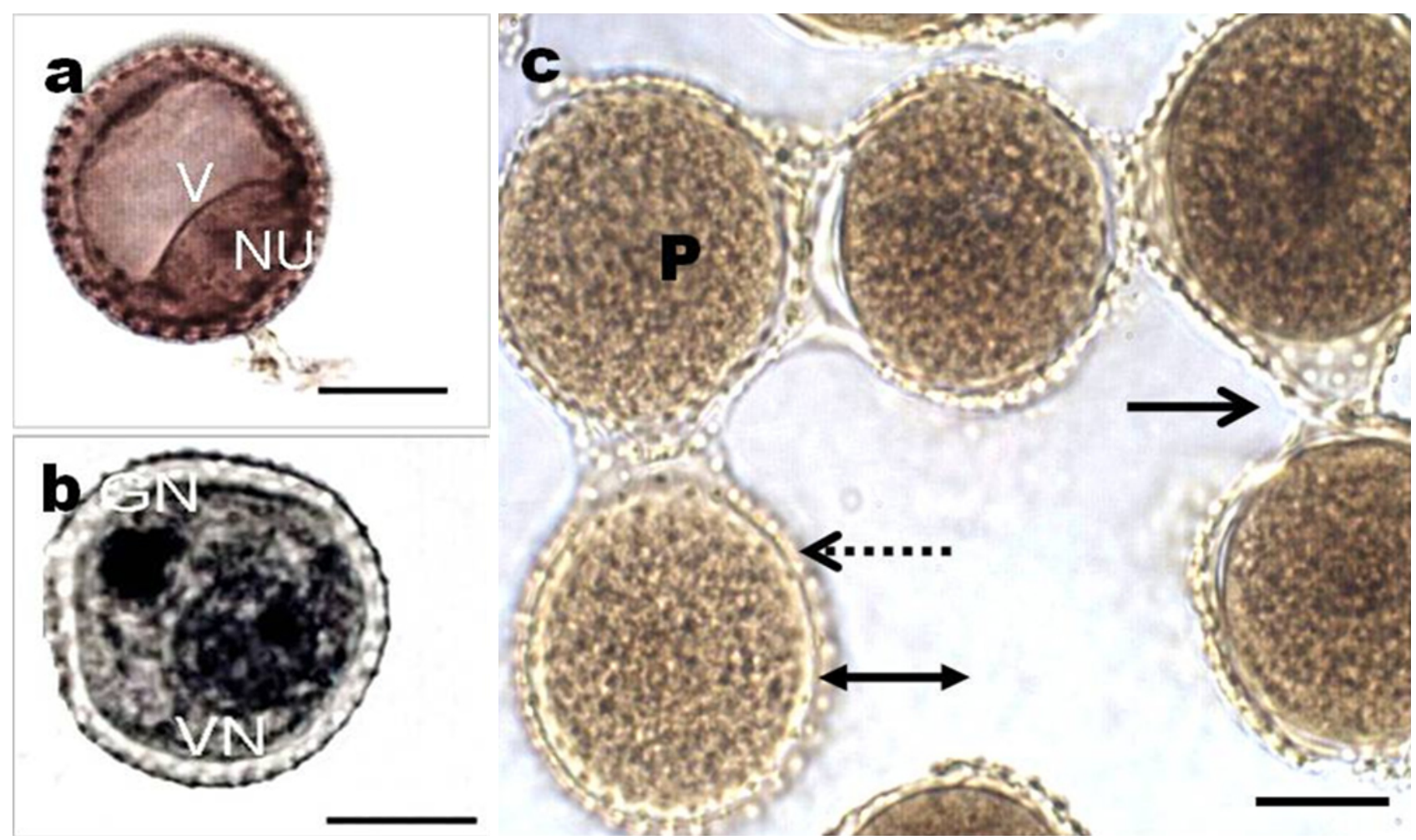

Fig. 7. a. Pollen with a large vacuole and nucleus displaced to one side, Bar $10 \mu \mathrm{m}$; b. Mature pollen grain with 2-celled, a generative cell and a vegetative cell at the shedding time, Bar $10 \mu \mathrm{m}$; c. Pollen unifying due to the wall bridges $(\rightarrow)$ and exine $(--->)$ and intine $(\leftrightarrow)$, Bar $10 \mu m$. V-Vacuol; NU-Nucleus; VN-Vegetative nucleus; GN-Generative nucleus; P-Pollen 
ther valves are closed (Fig. 8a, 8c). The parts, where valves are opened, are thicker in young anthers; while anthers mature, valve area becomes thin and transparent (Fig. 8ce).

Valves start to become visible by the time anther reaches the $0.7 \mathrm{~mm}$ dimension. In this stage, valves which are $0.5 \mathrm{~mm}$ in length and $0.3 \mathrm{~mm}$ in width, reach to a level of $1.3 \mathrm{~mm}$ in length, $0.9 \mathrm{~mm}$ in width and $10 \mu \mathrm{m}$ in thickness in mature anthers. Valves in SEM analysis are appear reticulate-smooth.

The valve is tied to the anther from upper and lower areas. As an identication that the valve holds on more tightly to the anther, elongation and wall thickening in endothecium are more than in other areas (Fig. 8d). When anther matures, the valve opens, deviating, through the lower part where the valve is tied to the anther, incohesively (Fig. 8b, f). Two valves existing in one anther open with a curving upwards, and not concurrently but consecutively (Fig. $8 \mathrm{~b})$. In Fig. $8 \mathrm{~b}$ and $\mathrm{f}$, anther valve, which was just opened, can be seen with the pollen grains upon and surrounding. Even in the stages where anther is incredibly mature, the valves remain paling and crouching while holding onto the upper part.

\section{Appandage}

Appandages are commonly observed in male flowers' anthers. Appandages form in mature or young anther's either apex (Fig. 4e-f; Fig. 8c) or on the upper edges, and
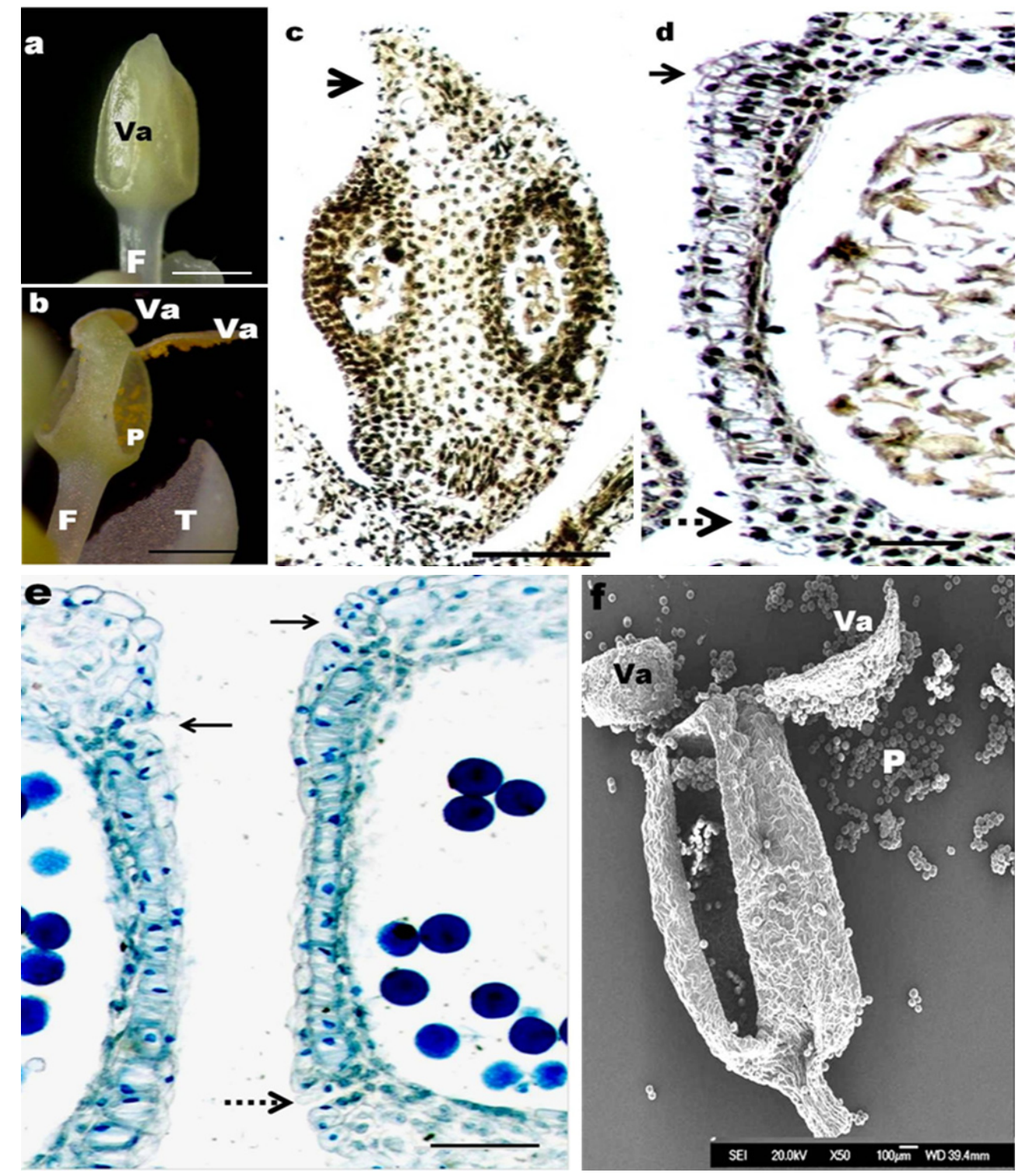

Fig. 8. a. Stereomicrograph of an anther before dehiscence, Bar 0.5mm; b. Stereomicrograph of an anther dehiscence by means of valve and yellow pollen grains in pollen sac, Bar $0.5 \mathrm{~mm}$; c. Longitudinal section of a young anther with valve and appandage $(\rightarrow), \operatorname{Bar} 100 \mu \mathrm{m}$; d. The endothecium at the upper $(\rightarrow)$ and lower region $(--->)$ of the valves of mature anther, $B$ ar $100 \mu \mathrm{m}$; e. Anther valves near to dehiscence, stained with Coomassie brilliant blue, Bar $100 \mu \mathrm{m}$; f. Scanning electron micrographs of anther dehiscence.Va-Valve; P-Pollen; F-Filament 
40

they do not carry vascular bundles. The cells with vacuole, and small and central nucleus, which are found in appandage (Fig. 4g), do not show dissimilarity from the cells in other parts of the anther. Starch grains, which are observed in the entire anther tissue, remain in these areas, as well, despite their limited number (Fig. 4g).

\section{Pollen morphology and pollen viability}

Pollen grains are surrounded by intine, and exine (Fig. 7c; Fig. 9b-c). There are thin, short, bulges those look alike needles on the exine wall (Fig. 9c). Pollen do not contain apertures. Some pollen grains remain in groups of mostly 2,3 or 4, tied to each other through wall bridges in anther loculus (Fig. 7c).

Based on the fact that there is a relationship between pollen viability and their talent of being stained with some stains, a viability test was applied through mature pollen; those were collected from anthers, being stained with Cotton blue which was prepared in lactofenol. Meiotic divi- sion in stained viable pollen was coordinated with $100 \%$ rate, which is justifying the present outcome.

Rarely, it drew attention that some pollen germination, and pollen tubes are formed in pollen sacs. This situation is, as is known, very rare in angiosperms. It was observed that, approximately, 1 or rarely 2 out of 30 pollen germination, and produce a tube in an anther.

\section{Discussion}

First development phases of male and female flower development in $L$. nobilis are pretty much alike. In male flower, as in female flower, apical meristem that starts to differentiate from vegetative meristem, which remains as an incisive bulge on growth points, transforms into floral meristem where flower primordia develop.

In male flower; 4 tepals, 8-10 stamens and a single carpel, whose differentiation was stopped in the very early
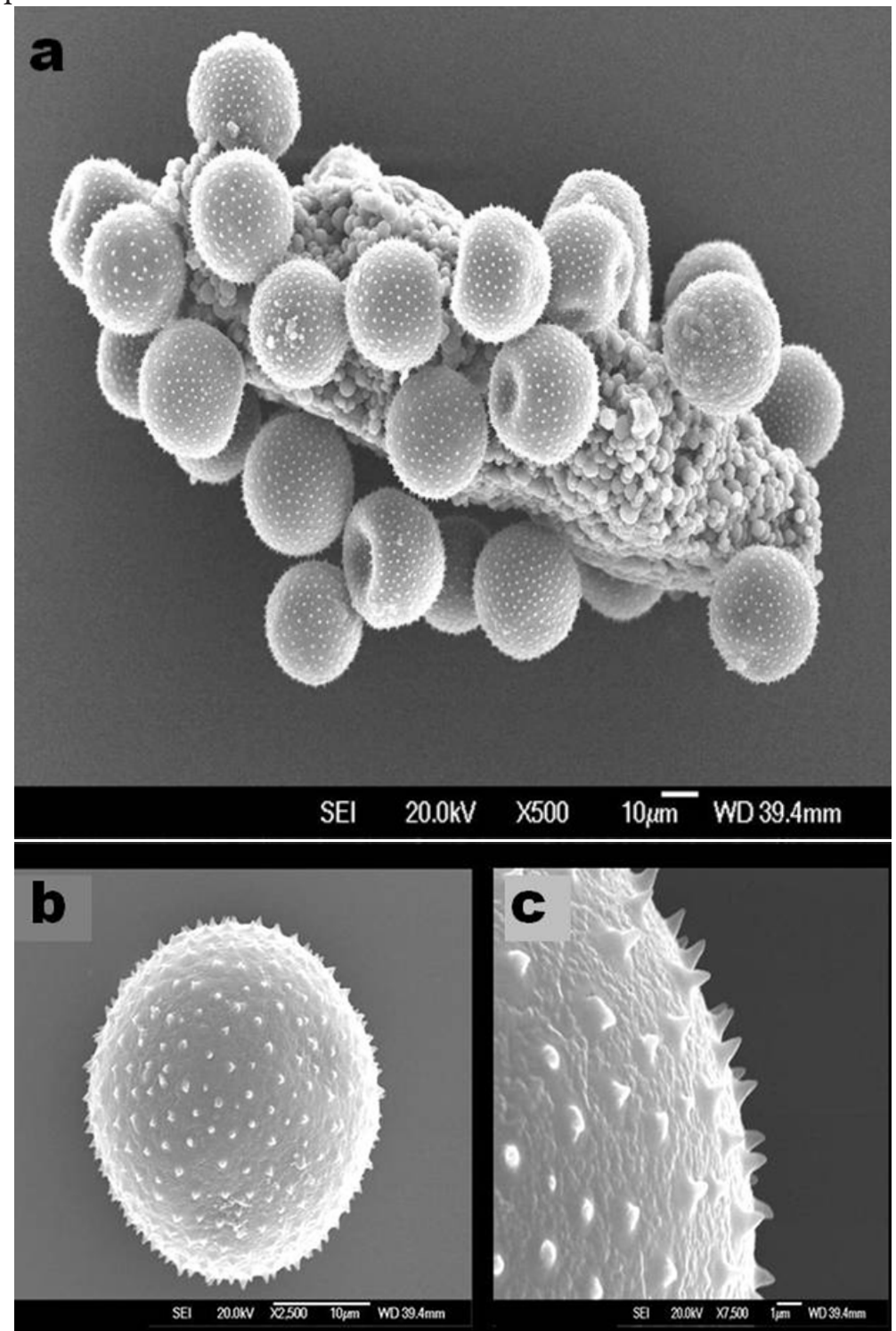

Fig. 9. a-c. Scanning electron micrographs of pollen grains 
stage of the development, are constituted from floral meristem.

In L. nobilis, although unisexual male flower development presents similarity to unisexual flower development in other species, there are differences in arrestting of carpel development. In Zea mays and its close relative Tripsacum dactyloides (DeLong et al., 1993; Li et al., 1997), the atrophy in sex organs was studied, in details, at gene level. In staminate flowers of corn, stamen and pistil development starts. The arrest of development occurs with the vacuolation in the cells near to the gynoecium summit and the loss of the organels (Le Roux and Kellogg, 1999).

In Mercurialis annua L. (Euphorbiaceae) (Durand and Durand, 1991), Spinacia oleracea L. (Amaranthaceae) (Sherry et al., 1993), and Thalictrum dioicum L. (Ranunculaceae) (Di Stilio et al., 2005) species, rudimentary organs do not exist in mature unisexual flowers. The development in L. nobilis male flower is in similar aspect.

In male flower buds, stamens are generated in three whorls. First, the stamens in the outermost whorl, then the ones in the innermost ring, and finally, the stamens in the mid most whorl differentiate. The stamens in the mid most ring are the ones which have the shortest filaments, and their anthers mature the earliest.

In Lauraceae, the most common flower structure in the family comprises two whorls of three tepals each, followed centripetally by three whorls of fertile stamens and one whorl of staminodes (Takahashi et al; 2001).

A development similar to the male flower was observed in Arabidopsis flowers and dioecious Silene latifolia. In $S$. latifolia, male flowers have long filaments, and they contain ten stamens. Five stamens those are closer to the centre are shorter, and they mature quicker compared to other stamens (Grant et al., 1994).

Arabidopsis flowers carry 6 stamens in 3 rings. Four of the stamens, which are long, are in the middle, and 2 short ones are on the sides. The stamens to develop first are the long ones (Scott and Dickinsonb, 2004).

The third whorl in Arabidopsis flowers contains 6 stamens, 4 medial (long) and 2 laterals (short). Stamen primordia in Arabidopsis appear during floral stage 5 (Sanders et al., 1999; Smyth et al., 1990), with the long stamens arising first.

The anther wall in male flower consists of 4 cell layers. Anther attributes of 13 kinds in Lauraceae family are well known. The formation style of the anther wall layers in 12 genus was studied. The number of microsporangia in anther of L. nobilis, similar to the 8 genus (Aiouea, Aniba, Apollonias, Cassytha, Licaria, Lindera, Mezilaurus) in the family, is bisporangiate (Kimoto and Tobe, 2001).

Tapetum layer, similar to the 7 genus (Aspidostemon, Beilschmiedia, Caryodaphnopsis, Cassytha, Cryptocarya, Endiandra, Potameia) in the family, is glandular (Watson and Dallwitz, 1992).

It is observed that the epidermis layer, which is found in the outmost part of the anther, consists of single layer of cells, and it remains still, as in Mognoliacaea, Liliaceae and Begoniaceae familes, till the end of the development without breaking down (Ünal, 1986).

The wall thickenings, in endothecium cells in male flower, give a PAS positive reaction in a strong manner. According to the results of Fossard's study in Chenopoidum rubrum, these restiform thickenings contain cellulose of a high percentage (Fossard, 1969).

Rarely, it is monitored that some pollen germinates in anthers, and form pollen tubes in male flower. It is known that this situation is exceptionally rare in Angiosperms. It is also observed in Viola, Oxalis and Lespedeza flowers, where pollen germinates in anther locus (Lee et al., 1979). With the studies carried out in Linum hirsutum L., it was identified that pollen grains germinate and form the pollen tubes inside the anther (Ünal and Yıldırım, 1995). Additionally, it is also scrutinized that, in Vicia genus, pollen germinate in anther locus; however, the number of germinated pollen is small (Dane and Meriç, 1999).

In Berberidaceae, anthers mostly open by 2 valves (Kim and Jansen, 1998). In Lauraceae, anthers dehiscence by 2 or 4 valves those open from the base to apex (Takahashi et al., 2001). In the male flowers of $L$. nobilis the anthers dehiscence by 2 valves open from the base to apex.

In male flower, there are starch grains in different volumes in tepal, anther, filament and nectarium tissues. Similar research conducted on Lilium (Cle' ment et al., 1996), Triticum aestivum L. (Dorion et al., 1996) and Oryza sativa L. (Sheroan and Saini, 1996), showed that conspicuous starch reserves are associated with anther growth and pollen development.

Well-developed vascular bundles are present in the lower part of the stigma, the style and the pericarp of the ovary. The histochemical identification of insoluble polysaccharides and lipid substances, within and around the vascular bundles, suggests that they are involved in the transport of these materials (Serrano et al., 2008).

Appandages are commonly observed in male flowers' anthers in L. nobilis. Appandages arise on either head or upper sides of the young or mature anther. The stamens of Nelumbo consist of a thin filament, an elongate anther, and a vegetative tip appendage (Kreunen and Osborn; 1999). The Ericaceae are one among only a few families in which stamens are characterized by the presence of various protrusions called appendages. While some Ericaceous taxa lack these staminal appendages, their shape, size, and position in the others are varied (Matthews and Knox, 1926; Stevens, 1971).

It is surveyed that some pollen in male flower form groups of 2, 3 and 4, being tied to each other through wall bridges in microsporangium. Dane and Meriç (1999) scrutinized pollen starches those are bond together through intin prolongations in $V$. hirsuta. Graybosch and Palmer (1998) explained this attribute, which they had observed in Glycine max L. Merr, as the sterility reason. 
42

Wall bridges may have originated from ctyoplasmic connections that existed during development at the time when the intine was laid down (Johri, 1984).

As generally observed in Lauraceae family, pollen exine surface of $L$. nobilis has a common elaborate outlook, in which spinouleses are realized effortlessly. In male flower, pollen grains do not contain apertures just like Lauraceae family members, and exine wall is quite thickened in $L$. nobilis. However, exine has become excessively thin mostly, in pollen grains in Lauraceae (Merwe et al., 1990).

\section{Conclusions}

The present study reveal the reproductive development of sex organs in dioecious species $L$. nobilis. The present results compare the ontogeny of female and male reproductive organs in L. nobilis and contribute the occurrence of unisexuality in plants.

\section{Acknowledgments}

This work was supported by the Research Foundation of Marmara University (BAPKO no: FEN-CYLP-181208-0291)

\section{References}

Caporali E, Carboni A, Galli MG, Rossi G, Spada A, Marziani Longo GP (1994). Development of male and female flower in Asparagus officinalis. Search for point of transition from hermaphroditic to unisexual developmental pathway. Sex Plant Reprod 7:239-249.

Cengiz Y (1979). Forest Research Institute Publications. Technical Reports Series no: 5.

Cheng P, Greyson Cri, Walden DP (1983). Organ initiation and the development of unisexual flowers in the tassel and ear of Zea mays. Am J Bot 70:450-462.

Cle'ment C, Burrus M, Audran JC (1996). Floral organ growth and carbohydrate content during pollen development in Lilium. Am J Bot 83:459-469.

Dane F, Meriç C (1999). Reproductive biology, pollen morphology, pollen germination (in situ), pollen tube growth of Vicia L. Turk J Biol 23:55-68.

Dellaporta SL, Calderone Urea A (1993). Sex detemination in flowering plants. Plant Cell 5:1241-1251.

Delong A, Calderon Urea A, Dellaporta SL (1993). Sex determination gene tasselseed 2 of maize encodes a shortchain alcohol dehydrogenase required for stage-specific floral organ abortion. Cell 74:757-768.

Di Stilio VS, Kramer EM, Baum DA (2005). Floral mads box genes and homeotic gender dimorphism in Thalictrum dioicum (Ranunculaceae)-a new model for the study of dioecy. The Plant J 41:755-766.

Dorion S, Lalonde S, Saini HS (1996). Induction of male sterility in wheat by meiotic-stage water deficit is preceded by a decline in invertase activity and changes in carbohydrate metabolism in anthers. Plant Physiol 111:137-145.

Durand B, Durand R(1991). Sex determination and reproductive organ differentiation in Mercurialis. Plant Sci 80:49-65.

Feder N, O’brien TP (1968). Plant microtechnique: some principles and new methods. Am J Bot 55:123-142.

Fossard RA (1969). Development and histochemistry of the endothecium in the anthers of in vitro grown Chenopodium rubrum L. Hot Gaz 130:10-22.

Grant S, Houben A, Vyskot B, Siroky J, Pan WH, Macas J (1994). Genetics of sex determination in flowering plants. Dev Genet 15:214-230.

Graybosch RA, Palmer RG (1998). Male sterility in soybean: an overview. Am J Bot 75(1):144-156.

Johri BM (1984). Embryology of angiosperms. Nord J Bot 8:98.

Kim YD, Jansen RK (1998). Chloroplast DNA restriction site variation and phylogeny of the Berberidaceae. Am J Bot 85(12):1766-1778.

Kimoto Y, Tobe H (2001). Embryology of Laurales: a review and perspectives. J Plant Res 114:247-261.

Kinney MS, Columbus JT, Friar EA (2003). Molecular evolution of the maize sex-determining gene tasselseed 2 in Bouteloua (Poaceae). Molec Phylogenet Evol 29:519-528.

Kreunen SS, Osborn JM (1999). Pollen and anther development in Nelumbo (Nelumbonaceae). Am J Bot 86(12):1662-1676.

Le Roux LG, Kellogg EA (1999). Floral development and the formation of unisexual spikelets in the Andropogoneae (Poaceae). Am J Bot 86 (3):354-366.

Lee WW, Nevins WM, Okuda H, White RB (1979). Unstable drift waves in a sheared magnetic field. Physic Rev Lett 43:347-350.

Matthews JR, Knox EM (1925). The comparative morphology of the stamen in the Ericaceae. Trans Proc Bot Soc Edinb 29:243-281.

Mitchell CH, Diggle PK (2005). The evolution of unisexual flowers: morphological and functional convergence results from diverse developmental transitions. Am J Bot 92(7):1068-1076.

Pearse AGE (1961). Histochemistry, theoretical and applied. $2^{\text {nd }}$ end. Boston.

Platt Aloia KA, Oross JW, Thomson WW (1983). Ultrastructural study of the development of oil cells in the mesocarp of avocado fruit. Bot Gaz 144(1):49-55.

Sanders PM, Bui AQ, Weterings K, Mcintire KN, Hsu YC, Lee PY, Truong MT, Beals TP, Goldberg RB (1999). Anther developmental defects in Arabidopsis thaliana male-sterile mutants. Sex Plant Reprod 11:297-322.

Scott RJ, Spielman M, Dickinsonb HG (2004). Stamen structure and function. Plant Cell 16:s46-s60.

Serrano I, Suárez C, Olmedilla A, Rapoport HF, Rodríguez García Mİ (2008). Structural organization and cytochemical 
features of the pistil in olive (Olea europaea 1.) cv. 'Picual' at anthesis. Sex Plant Reprod 21:99-111.

Sheroan IS, Saini HS (1996). Drought-induced male sterility in rice: changes in carbohydrate levels and enzyme activities associated with the inhibition of starch accumulation in pollen. Sex Plant Reprod 9:161-169.

Sherry RA, Eckard KJ, Lord EM (1993). Flower development in dioecious Spinacia oleracea (Chenopodiaceae). Am J Bot 80:283-291.

Smyth DR, Bowman JL, Meyerowitz EM (1990). Early flower development in Arabidopsis. Plant Cell 2:755-767.

Stevens PF (1971). A classification of the Ericaceae: subfamilies and tribes. Bot J Linn Soc 64:1-53.

Takahashi M, Herendeen PS, Crane PR (2001). Lauraceous fossil flower from the Kamikitaba locality (Lower coniacian; upper cretaceous) in Northeast Japan. J Plant Res 114:429434.
Topçuoğlu N, Selvi N, Dokumaci E (2009). The comparison of critical point drying and drying with Hexamethyldisilazane methods for the preparation of mice Tissues for scanning electron microscopy ii. Lung and stomach Findings. Anad Univ J Sci Techn 1:127-132.

Ünal M (1986). A comparative cytological study on compatible an incompatible pollen tubes of Petunia hybrida. Ist Univ Fen Fak Mec 51:1-12.

Ünal M, Cansev Y (1995). Structural differences of the stigmatic papillae in distylous Linum hirsutum and monostylous Linum tenuifolium. Acta Bot Hung 49(1-2):245-251.

Watson L, Dallwitz MJ (1996). Lauraceae in the families of flowering plants. http://biodiversity.uno.edu/delta/. 